\title{
The Performance of Hybrid Constructed Wetland System for Treating the Batik Wastewater
}

\author{
Erina Rahmadyanti ${ }^{*}$, Oktavia Audina ${ }^{1}$ \\ 1 Departement of Civil Engineering, Faculty of Engineering, Universitas Negeri Surabaya, Kampus Unesa \\ Ketintang, Surabaya, 60231, Indonesia \\ * Corresponding author's e-mail: erinarahmadyanti@unesa.ac.id
}

\begin{abstract}
The batik industry is one of the Indonesian economic drivers. However, most of the batik industries discharge their wastewater without any prior treatment, thus endangering the environment. This research aims to investigate the ability of hybrid constructed wetlands (CWs) system using Canna indica in the batik wastewater treatment. The parameters studied were chemical oxygen demand (COD), total suspended solid (TSS), and oil and grease (FOG) with 3, 5, and 7 days of hydraulic retention time (HRT). The results indicate that the hybrid constructed wetland system using Canna indica optimally gains the COD and FOG removal efficiency on day 3 at $89.61 \%$ and $89.53 \%$, while the TSS removal efficiency on day 5 at $98.74 \%$. Despite the high removal efficiency, the effluent parameters remain below the standards for direct discharge into waterbodies. Therefore, further research is needed to investigate the appropriate pre-/advanced treatment to be combined with the hybrid constructed wetland in batik wastewater treatment.
\end{abstract}

Keywords: batik industry, wastewater, hybrid constructed wetland, Canna indica.

\section{INTRODUCTION}

Indonesia is one of the countries famous for its batik, besides China, Thailand, Africa, Malaysia, Sri Lanka and Azerbaijan. Technique, symbolism, and culture of making the batik color using hands on cotton and silk, have become one of the ways of life for the people of Indonesia. The batik tradition itself is carried from generation to generation. Batik is done by Indonesians in various areas, from an early age to adulthood. UNESCO recognized batik as a cultural heritage of humanity and a native of Indonesia.

The UNESCO's recognition makes batik increasingly recognized by the world. The image of batik is raised increasingly often. Batik is no longer seen as traditional clothing or clothing that is formal, old, and stiff. Furthermore, batik is currently favored by everyone from children to adults. The Ministry of Trade reported that during 2006-2010, the batik industry had increased 16\% of its production (Steelyana, 2012).
The batik production continues to increase along with the consumer demand, both domestically and abroad. Batik in Indonesia is produced at various scales ranging from home industries, small and medium industries to large industries.

The increase in batik production and the vast scale of the batik industry has the potential to have a negative impact on the environment. The dominant environmental problem is the wastewater generated from the activities of the batik making process. It is estimated that the use of water in the process of making batik on average is approximately $25-50 \mathrm{~m}^{3}$ per meter of batik cloth. The data from the batik production in Indonesia averages 500 million meters per year, which means it requires 25 million $\mathrm{m}^{3}$ of water a year. The water supply for the batik industry per year is equivalent to the provision of clean water for 2,500 households. Nearly 85 percent of clean water used for the batik production process becomes wastewater with a large volume, thick color, and pungent odor (Indrayani, 2018). 
The batik wastewater is generated from the industrial production (dyeing, rinsing the wax, and and flushing) (Mukimin et al., 2018).The batik wastewater contains wax, resin, colorant, as well as silica which are highly contained COD and high $\mathrm{pH}$ variation range. In the soaking and boiling stages of the batik making process, the wastewater had $\mathrm{pH}$ of $11-12$, while the first/second step flushing obtained $\mathrm{pH}$ 6-7.5 (Birgani et al., 2016). In addition, the batik wastewater also contains high concentrations of synthetic dyes, BOD, and heavy metals (Tangahu et al., 2019).

In Indonesia, almost every region has batik with characteristics, motifs, and colors and different chemical composition, but in general the process of making batik remains the same. Each industrial process generates wastewater with different characteristics due to the chemicals used (Rashidi et al., 2013). Various pollutants contained in the batik wastewater are discharged into the river directly without undergoing treatment. This condition, if it occurs continuously, has the potential to pollute the environment, especially water bodies.

The rapid development of the batik industry in Indonesia accompanied by the high possibility of environmental pollution encourages studying various alternatives related to the batik wastewater treatment technology. In the batik wastewater treatment, plastic-coated titanium dioxide $\left(\mathrm{TiO}_{2}\right)$ is used to separate the batik wastewater in dyeing process. This technology is able to obtain the removal efficiencies in 5 days retention time for COD, BOD, and TSS respectively 97\%, 23\%, and $71 \%$ respectively (Arifan et al., 2018).

Another research was conducted by Lee et al. (2015) who conducted flocculation coagulation treatment of aluminum sulfate with aloe vera (ALAV) and magnesium sulfate with aloe vera (MGAV) as the main treatment of methylene blue. They found that ALAV has the dyeing removal efficiency at 50-55\%, while the MGAV dyeing removal efficiency at $60-70 \%$. Thus MGAV, as hybrid coagulant provably is more effective in removing dye.

The combination of bio-equalization and electro-catalytic has also been studied to treat the batik wastewater. At the time of HRT 48 hours, the achieved removal efficiency of TSS, ammonia $\left(\mathrm{NH}_{3}\right)$, and oil \& fat for bioequalization reached $72 \%, 78 \%$, and $39 \%$, respectively,. In addition, bioequalization has also proven to be very significant in removing wax. In turn, electro-catalysis can reduce COD and color more efficiently by $32 \%$ and $65 \%$, respectively. Furthermore, the COD removal increased to $62 \%$ at 180 minutes (Mukimin et al., 2018). Other processing technologies that are also studied to treat batik wastewater, especially wax, are using baffle tanks and dissolved air flotation (DAF) by adding chemical substances before carrying out biological treatments (Dehghani et al., 2014; Rashidi et al., 2013).

Most batik wastewater treatment technologies are expensive and complicated due to the complexity of the technology and chemicals used. Therefore, a simple, efficient technology in terms of cost and energy is needed, easily implemented by small industries so that it runs sustainably. CWs is a technology that is able to fulfill various aspects (Mthembu et al., 2013; Elzein \& Elgawad, 2016; UN habitat, 2008).

In CWs systems, plants have an important role in removing the organic and inorganic substances in the wastewater (Sazmas \& Hasar, 2008; Perdana et al., 2018). Among the plants used, Canna Indica capably removes heavy metals from soil, water, and air (Cule et al., 2016; Darsini et al., 2015; Panrare \& Tondee, 2015; Sharma \& Sinha, 2016; Yadav et al., 2012).

There are 2 types of CWs, horizontal subsurface flow (HSSFCWs) and vertical sub surface flow (VSSFCWs). HSSFCWs is significant in removing BOD and TSS in secondary treatment, but it is not effective in the nitrification processes, because of the limited oxygen transfer capacity. Meanwhile, VSSFCW is proposed due to its ability of higher oxygen transfer capacity. Moreover, VSSFCW does not require larger space. However, VSSFCW has some limitations, for example, its inefficiency in removing solids and causing clogging if the media selected is incorrect. Considering those conditions, combining HSSFCW and VSSFCW as a hybrid CW is highly recommended, because it will cover up each weakness of the system (UN-Habitat, 2008).

Furthermore, the advantages of the hybrid system are: (1) it has a better processing effect than a single system; (2) minimal breeding of mosquitoes; (3) involvement of natural processes such as earth gravity, sunlight, gravel and sand in the filtration process, as well as plants to remove waste compounds; (4) it requires less power (especially for pumping engines); and (5) it has more stable pace process. However, the hybrid system is also has weaknesses, such as large size, and requirement of experts (system knowledge, 
construction, design, and supervision) (Staufer \& Spuhler, 2018; ITRC, 2003; Halverson, 2004).

On the basis of some technological limitations that have been studied in the treatment of the batik wastewater and the advantages of hybrid CWs, this study aims to determine the ability of hybrid CWs in treating the batik wastewater in an effort to minimize the occurrence of environmental pollution in water bodies.

\section{MATERIAL AND METHODS}

\section{Wastewater samples}

The samples were taken from Kampoeng Batik Jetis Sidoarjo. These samples were from the batik boiling process (Figure 1). This process involves rinsing the wax after the dying process. The reason in using the wastewater from rinsing process is due to the high concentrated chemical substances compared to the other two processes (dying and flushing). During soaking, COD level is $3,950 \mathrm{mg} / \mathrm{L}$, while boiling, the COD level is 13,600 mg/L with pH 12.1 (Birgani et al., 2016).

\section{Hybrid constructed wetlands}

The constructed wetland hybrid reactor used in this study can be seen in Figure 3. This model is basically realized from the design concept of hybrid CWs as shown in Figure 2. In the model, VSSFCW is placed first, because it has the ability to process ammonia into nitrate (nitrification) better than HSSFCW, then followed by HSSFCW which is responsible for the process of changing nitrate into nitrogen gas (denitrification). Each unit system of VSSFC and HSSFCW is made of glass with a length, width and height of $100 \times 50 \times 60 \mathrm{~mm}$. The media used are 5-10 mm gravel and river sand with $0-4 \mathrm{~mm}$ size variations used on vertical and horizontal CW. In the influent and effluent section, a $3 / 4$ inches diameter pipe is used. The distance of $30 \mathrm{~cm}$ is set on the top layer of media to free board.

\section{Wetland plants and acclimatization}

The wetland plant used in this study is Canna indica. Canna indica was chosen because of its abundance, ease to adapt and lack of special treatment requirement in its maintenance. The use of Canna indica in various types of wastewater treatment using CWs has been widely carried out because it has a fast growth rate, greater leaf area, has an extensive root system.

The effectiveness of Canna indica was already proven in several studies. Those studies proved that CWs using Canna indica are able to remove and absorb nutrients better than those CWs that do not use it (Cui et al., 2010).

Canna indica in the CWs is also widely used in the industrial wastewater treatment, one of which is in the paper industry wastewater treatment. It was proven effective in reducing the organic material dye and organic chlorine components (Darsini et al., 2015). This is because Canna indica has important role in phytoremidiation process which efficiently removes heavy metals utilizing its roots and leaves (Cule et al., 2016; Darsini et al., 2015).

Before being used in hybrid CWs, Canna indica is acclimatized for 2 weeks. The acclimation process is done by watering the plants using tap water for 1 week. Afterwards, the plants are subjected to adaptation with batik wastewater through

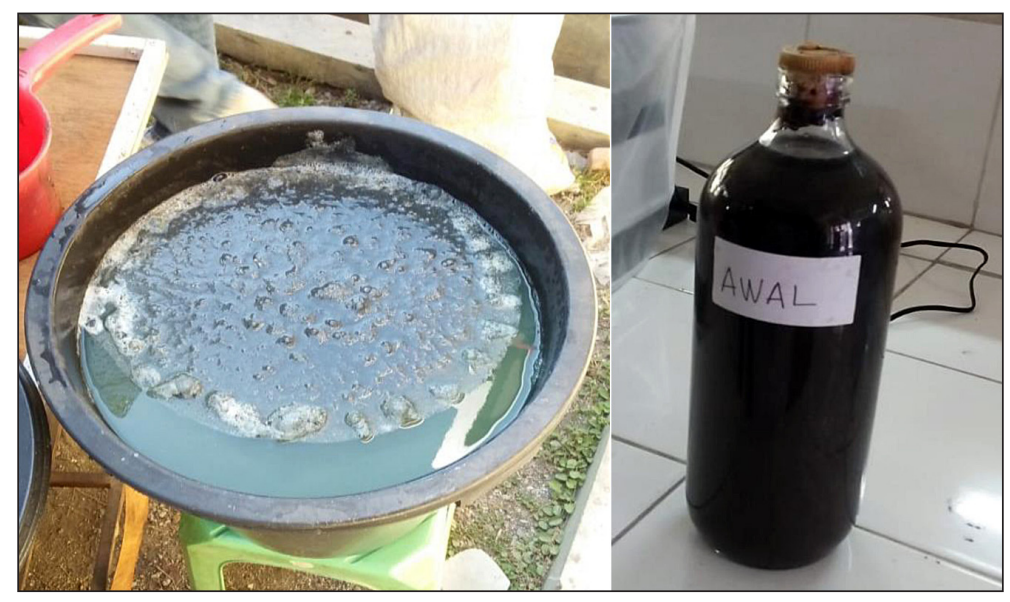

Figure 1. The raw sample of wastewater from the batik boiling process 


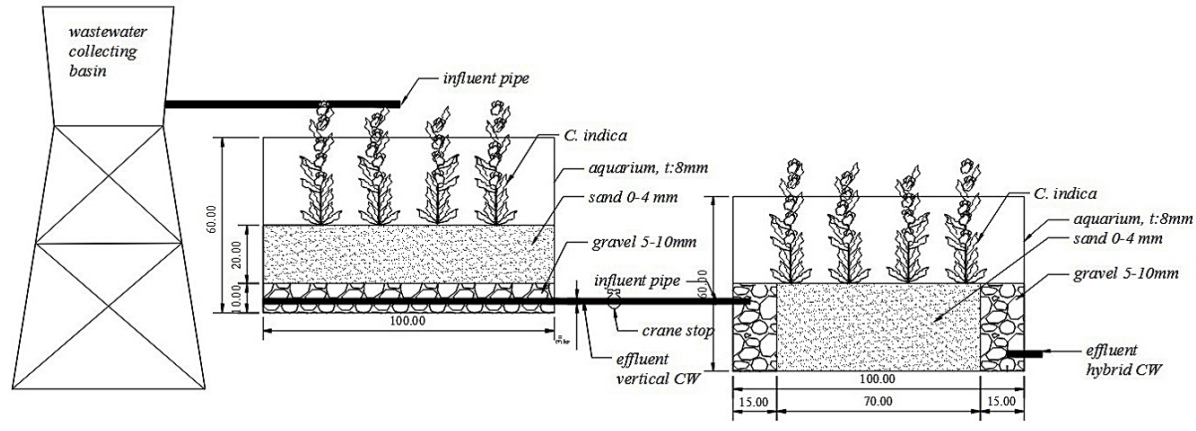

Figure 2. The concept of hybrid constructed wetlands

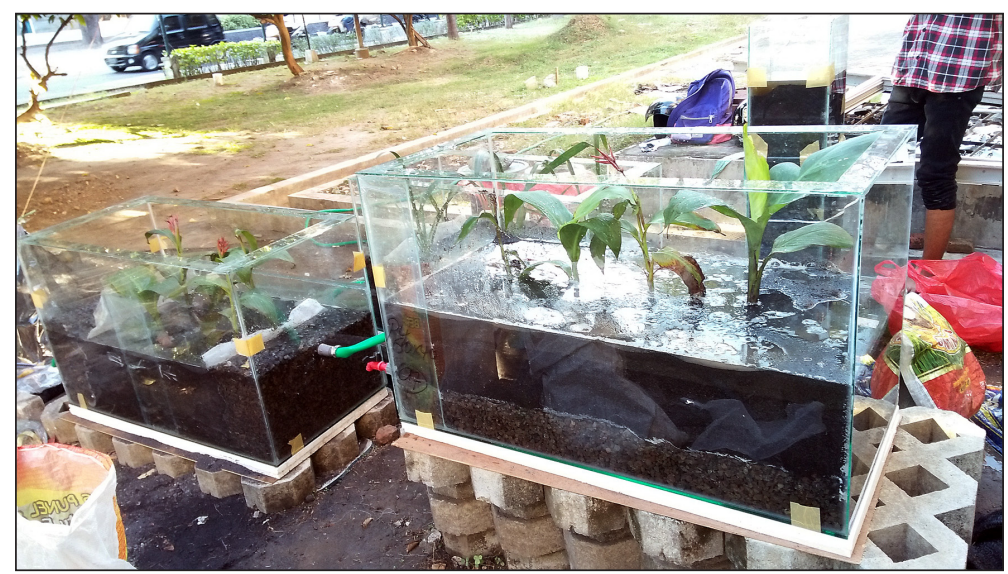

Figure 3. The model hybrid constructed wetlands system

a process of watering with gradual concentration variations of $25 \%, 50 \%$ and $75 \%$. After the acclimatizing process, the plant shows its adaptability and is able to bloom flowers, has both healthy leaves and stems, and develops new buds (Jayaweera et al., 2008; Kamaruzaman et al., 2011).

\section{Experimental setup}

The raw wastewater samples were placed in a wastewater collecting basin for 24 hours. Furthermore, the drainage of the wastewater samples was placed at the VFCW unit with a discharge of $6 \mathrm{~mL} / \mathrm{min}$. The effluent of the VSSFCW unit then entered the HSSFCW unit. The observation process was carried out with a variation of HRT of 3,5 , and 7 days.

\section{Data analysis}

This research is an experimental laboratory study that aims to determine the effectiveness of hybrid CWs in treating the batik wastewater. The effectiveness of hybrid CWs is observed from its removal ability on COD, TSS, and FOG parameters.
COD is defined as the amount of oxygen needed to carry out chemical reactions in order to oxidize organic matter into $\mathrm{CO}_{2}$ and hydrogen dioxide $\left(\mathrm{H}_{2} \mathrm{O}\right)$ (Ajayi et al., 2016). In turn, the amount of particulate matter dissolved in water is stated as TSS (Parwati \& Purwanto, 2017) and FOG is a solution or emulsion material made from glycerol esters, fatty acids or triglycerides (Deghani et al., 2014).

In this research, the parameters of COD, TSS, and FOG become the dependent variables which are affected by the independent variables. These parameters are used to explain the efficiency of the hybrid system. Meanwhile, HRT becomes the independent variable which causes the change of the dependent variables. Three HRTs are used in this research observation, namely 3, 5 and 7-days. In addition, the control variable used is Canna indica and the discharge flow of $6 \mathrm{~mL} /$ minutes.

The data are processed using multivariate analysis of variance (Manova). Manova is a statistical method to measure the effect of the relationship between several independent variables that are categorical (nominal or ordinal data) with several dependent variables that are metric (interval or ratio data) (Sutrisno \& Wulandari, 2016). 
The data from the effluent are compared to the wastewater standard and water classification set by the government (The Indonesian Minister of Environment Regulation No. 5/2014) especially on the effluent in order to determine the effectiveness of hybrid CWs, as seen on Table 1.

\section{RESULTS AND DISCUSSION}

\section{Sample characteristics}

The research samples were taken from the batik wastewater generated from the boiling in the rinsing process. The wastewater has such physical characteristics as turbid black, green, thick liquid with reeking smell after several days.

The sample was stored in a labelled bottle as initial wastewater and immediately brought to the laboratory for further observations. The observations were made on the COD parameters was carried out using the closed reflux method; while both TSS and FOG were done using the gravimetric method.

Table 1. The wastewater characteristics from the boiling process

\begin{tabular}{|c|c|c|}
\hline $\begin{array}{c}\text { Observed } \\
\text { parameter }\end{array}$ & $\begin{array}{c}\text { Raw sample } \\
(\mathrm{mg} / \mathrm{L})\end{array}$ & $\begin{array}{c}\text { Standards regulations } \\
(\mathrm{mg} / \mathrm{L})\end{array}$ \\
\hline COD & 12,000 & 150 \\
\hline TSS & 3,180 & 50 \\
\hline FOG & 9,740 & 3 \\
\hline
\end{tabular}

Table 1 shows that overall both the COD, TSS and FOG parameters have the values exceeding the threshold set by the rules as stated in The Indonesian Minister of Environment Regulation No. 5/2014 concerning standard value for textile industrial wastewater. In fact, in particular the COD parameters obtained a value of $12,000 \mathrm{mg} / \mathrm{L}$ $\mathrm{O}_{2}$ far above the COD value contained in the batik wastewater produced by Malaysia, amounting to 13,600 mg/L O (Birgani, et al., 2016).

The samples on the effluent from hybrid CWs were taken on days 3,5 and 7 in order to compare the test results and determine the effectiveness in using VSSFCW and hybrid system. Nevertheless, the effluents of both reactors are similar, i.e. greenish yellow colour, foamy consistency, and reeking smell.

Hereafter, the Manova test is conducted in order to calculate the difference of the significance testing average value among groups at the same time $(3,5$, and 7 days) for two or more dependent variables (Sutrisno \& Wulandari, 2018) (see Table 2). While conducting the Manova test, there are two prerequisites conditions, i.e. having the normality and homogeneity test for the data.

The Manova test is used to test if there is any effect in using each technology (independent variables) in the observed time period (3,5, and 7 days). The results of the Manova test show that the Sig. is 0.000 , meaning there is no effect for both treatments (using VSSFCW and hybrid system) in the selected parameters. This refers to when Sig $<0.05$, it means that there is effect on the treatment).

Table 2. The results of multivariate test

\begin{tabular}{|l|l|c|c|c|c|c|}
\hline & Effect & Value & F & Hypothesis df & Error df & Sig. \\
\hline & Pillai's Trace & 1.000 & $34,837.103^{\mathrm{b}}$ & 3.000 & 10.000 & .000 \\
\hline & Wilks' Lambda & .000 & $34,837.103^{\mathrm{b}}$ & 3.000 & 10.000 & .000 \\
\hline & Hotelling's Trace & $102,851.131$ & $34,837.103^{\mathrm{b}}$ & 3.000 & 10.000 & .000 \\
\hline & Roy's Largest Root & $102,851.131$ & $34,837.103^{\mathrm{b}}$ & 3.000 & 10.000 & .000 \\
\hline & Pillai's Trace & 1.998 & $4,786.546$ & 6.000 & 22.000 & .000 \\
\hline & Wilks' Lambda & .000 & $8,206.658^{\mathrm{b}}$ & 6.000 & 20.000 & .000 \\
\hline & Hotelling's Trace & $9,842.980$ & $13,927.470$ & 6.000 & 18.000 & .000 \\
\hline & Roy's Largest Root & $8,578.941$ & $31,456.117^{\mathrm{c}}$ & 3.000 & 11.000 & .000 \\
\hline & Pillai's Trace & 1.000 & $15,214.407 \mathrm{~b}$ & 3.000 & 10.000 & .000 \\
\hline & Wilks' Lambda & .000 & $15,214.407^{\mathrm{b}}$ & 3.000 & 10.000 & .000 \\
\hline & Hotelling's Trace & $4,564.322$ & $15,214.407^{\mathrm{b}}$ & 3.000 & 10.000 & .000 \\
\hline & Roy's Largest Root & $4,564.322$ & $15,214.407^{\mathrm{b}}$ & 3.000 & 10.000 & .000 \\
\hline & Pillai's Trace & 1,962 & 187,527 & 6.000 & 22.000 & .000 \\
\hline & Wilks' Lambda & .000 & $716,488^{\mathrm{b}}$ & 6.000 & 20.000 & .000 \\
\hline & Hotelling's Trace & $1,786.631$ & $2,679.946$ & 6.000 & 18.000 & .000 \\
\hline & Roy's Largest Root & $1,761.167$ & $6,457.614 \mathrm{~b}$ & 3.000 & 11.000 & .000 \\
\hline
\end{tabular}


In conclusion, though two treatments (VSSFCW and hybrid system) have different effects on the parameters of COD, TSS and FOG, they basically have no significant effect on the removal efficiency, in order to meet the standard wastewater quality and water classification set by the government. This is due to the value derived from the testing value of 0.000 using Pillar Trace, Wilks' lambda, Hotelling's Trace, and Roy's Largest Root to the sig. $=0.05$ ( Sig. $=0.000<0.05$ ).

\section{COD removals}

The highest COD removal efficiency using hybrid CWs occurs on day 3 at $89.61 \%$ (see Figure 4). The results are in line with the previous research, which found that hybrid CWs (VF-HF) has a COD removal efficiency at 80-89\% (Meng et al., 2014; Otieno et al, 2017; Melian et al., 2010).

Planting vegetations in CWs have provably higher organic susbtance removal than those without (Cui et al., 2010; Sindilariu et al., 2009; Shelef et al., 2013; Otieno et al., 2017). This indicates that planting Canna Indica, helps in removing the organic components of the batik wastewater in CWs (Darsini et al., 2015; Sharma \& Sinfa, 2016; Yadav et al., 2012). However, other studies mention that although hybrid CWs are not planted, they are still able to remove COD levels as both sun and soil contribute in providing good environmental conditions in maintaining the microorganisms' growth as well as degrading oragnic material in wastewater (Otieno et al., 2017; Meng et al., 2014).

The COD removal efficiency in the wetland technology carries out three steps (physical, chemical, and biological steps). First, the contact occurs between pollutants in wastewater and substrate media CWs. In the second step, the deposition process occurs. During this process, the microorganisms removed the carried organic substances (Halverson, 2004; ITRC, 2003).

On day 5 and 7, the COD removal efficiency dropped because of the decreasing pollutant absorption ability of plants in reactor. This condition is because the oxygen supply in the roots decrease result on the declining aerobic microbial activity (Gunawan et al., 2013).

\section{TSS removals}

The TSS removal efficiency using hybrid CWs along the designated retention time $(3,5$, and 7 day) (see Figure 5). The highest efficiency is on day 3, ranging from $94.53 \%$ to $98.74 \%$, yet it continuedly declines on day 5 and 7 . At the highest level, the TSS contents decreased from $3,180 \mathrm{mg} / \mathrm{L}$ to $40 \mathrm{mg} / \mathrm{L}$. However, on day 5 , it declined up to $98 \mathrm{mg} / \mathrm{L}$ and continued to decline on day 7 up to $54 \mathrm{mg} / \mathrm{L}$.

The optimum TSS removal efficiency in hybrid CWs occurs on day 5 at $98.74 \%$. This can occur because of the important role of physical processes in removing contaminants, especially inorganic. In addition, the existence of gravity causes a sedimentation process in which particles are suspended apart from water. Aside from gravity and the substrate, vegetation (plant) also supports the filtration process during the sedimentation. The plant's root system aids in filtering the solids in the wastewater (Otieno et al., 2017). Fiber roots are better in aiding the filtration process because they are able to spread and reach a larger area (Sembiring et al., 2013). The TSS removal

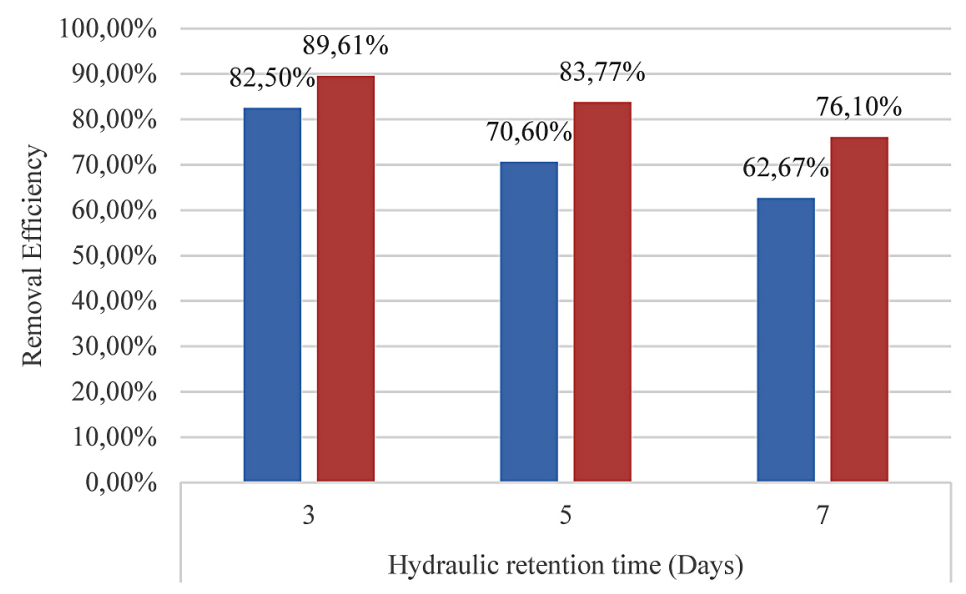

Figure 4. The COD removal efficiency 


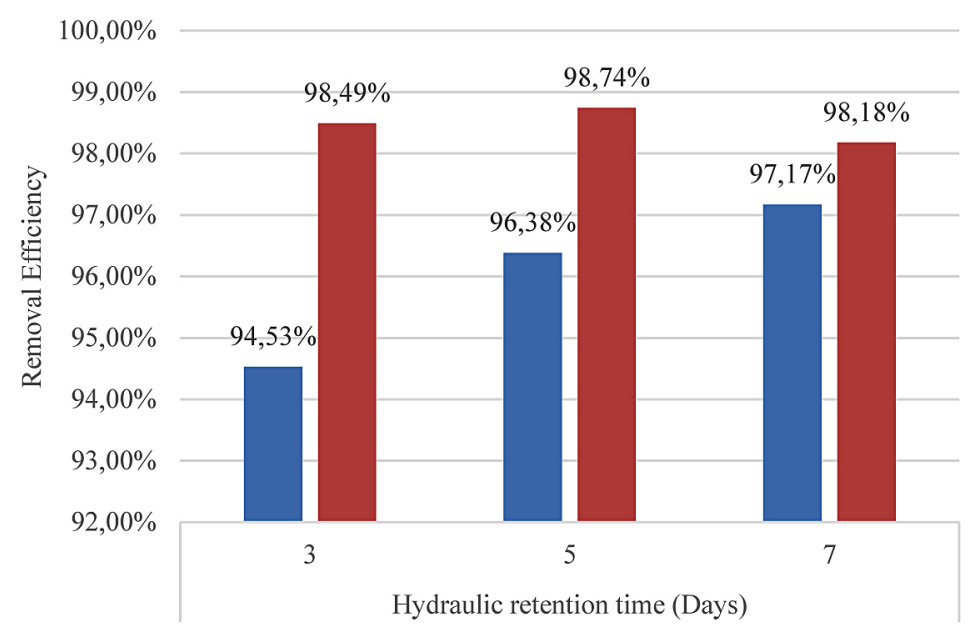

Figure 5. The TSS removal efficiency

efficiency appropriated with both speed and length of sedimentation particles (ITRC, 2003). Yet, the declining removal efficiency occured on day 7 because the hybrid CWs unit is already saturated by the contaminants and solid particles in which the resulting floating particles cannot be precipitated and removed (Sindilariu et al., 2009). This condition causes the optimum time for TSS removal to occur on the 5th day with a removal efficiency value of $98.74 \%$. The results are inline as stated by Meng et al. (2014), in their previous study, it was mentioned that the TSS removal efficiency using hybrid CWs is $78-98 \%$.

\section{Oil and grease removals}

The FOG removal efficiency using hybrid CWs reached the highest level at $89.53 \%$ and $79.59 \%$. on the day 3 and 5, respectively (see Figure 6). However, the figure shows that its efficiency declined in the day 7 of retention time up to $10 \%$.

The optimal FOG removal efficiency was achieved at $89.53 \%$ on the day 3 of retention time. FOG is successfully removed through the pretreatment process by using dissolved air flotation (DAF) adding with chemical compounds before the biological treatment. DAF added with alum and acidification capably remove FOG with the removal efficiency of $85-95 \%$ (Dehghani et al., 2014). Removing the wax content in the batik wastewater, the pre-treatment process possibly reduces the COD level (Rashidi et al., 2013).

\section{The HRT influence in contaminant removal}

HRT has a significant role in pollutant removals in the wastewater treatment. During the treatment process, a set of microbes is formed in the CWs and remove contaminants (depended on the

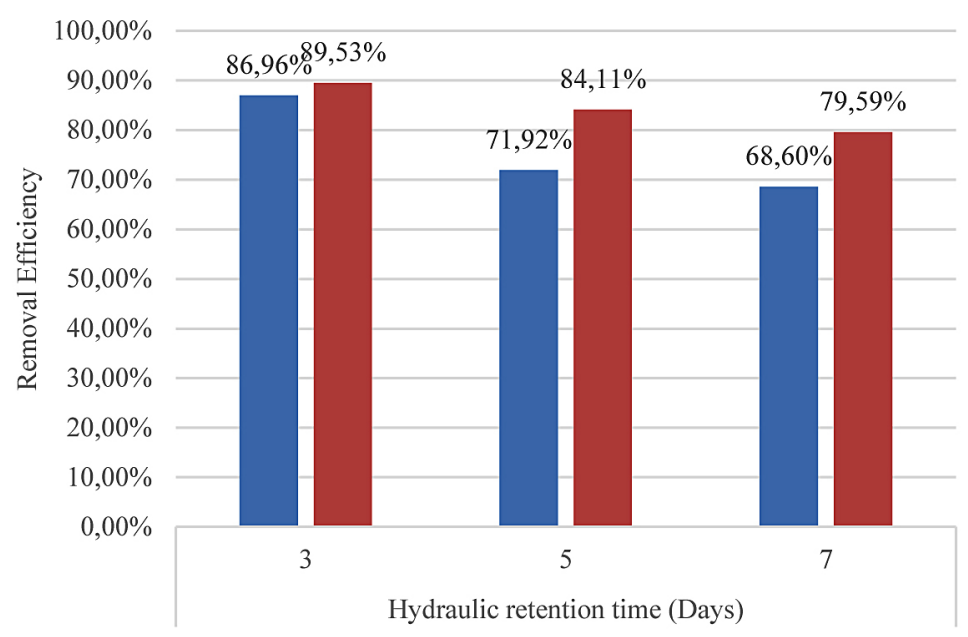

Figure 6. The FOG removal efficiency 
retention times in the reactor (Wu et al., 2015). Otieno et al. (2017) mention that the incresing efficiency is showed on the retention time on days 3, 5 , and 7 in the hybrid CWs. The Otieno's research is inversely proportional to the research conducted by the researchers. In CWs, the pollutant removal process involves many disiplines such as physics, chemistry, and biology (ITRC, 2003).

Therefore, each CWs has different efficiency, which depends on the discharged wastewater and vegetation used in the process (Stein \& Paul, 2005; Halverson, 2004). In some cases, the HRT has a different effect on removal efficiency, depending on the ambient temperature and the plant species used. Supported by Wu et al., (2015), which states that the short HRT is caused by an imperfect wastewater denitrification process.

\section{Effluent standards}

The results of hybrid CWs processing for all observation parameters at each HRT are shown in Table 3.

The results show that of the three parameters tested, (COD, TSS, and FOG) the closest value that meets the standard water quality of the TSS content were on day 3 and 5. However, both COD and FOG, although having high removal efficiency, do not meet the specified value standardized either in any retention time $(3,5$, or 7$)$. It is concluded that CWs using hybrid technology is not effective in filtering out the contaminants in the effluents from boiling process of the batik production.

Table 3. The effluent parameters generated from hybrid CWs

\begin{tabular}{|c|c|c|c|}
\hline \multirow{2}{*}{$\begin{array}{c}\text { Observed } \\
\text { parameter }\end{array}$} & \multicolumn{3}{|c|}{$\begin{array}{c}\text { Treated effluent of hybrid CWs on each } \\
\text { HRT (days) }\end{array}$} \\
\cline { 2 - 4 } & 3 & 5 & 7 \\
\hline $\operatorname{COD}(\mathrm{mg} / \mathrm{L})$ & 1,247 & 1,948 & 2,868 \\
\hline TSS $(\mathrm{mg} / \mathrm{L})$ & 48 & 40 & 54 \\
\hline FOG $(\mathrm{mg} / \mathrm{L})$ & 1,020 & 1,548 & 1,988 \\
\hline
\end{tabular}

The effluents resulted from the hybrid CWs were then compared to the water classification standards set by the goverment (Indonesian Government Regulation No. 82/2001) regarding managing the water quality and controlling water pollution. The expected results are how the effluents can be categorized as safe (based on the level of chemical contents of each designated parameter) (see Table 4).

According to the analysis, the treated effluents from hybrid CWs on day 3 contained the least contaminants, yet these also remain below the standard set by the goverment regarding the water class standards (I, II, III, or IV). Highly possibly, this is caused by both COD and FOG levels that do not meet the standard for the classification of water use.

\section{CONCLUSIONS}

Combining VSSFCW and HSSFCW technology into hybrid CWs technology using Canna Indica enabled to achieve COD and FOG removal efficiency at $89.61 \%$ and $89.53 \%$ respectively on day 3 while the TSS removal efficiency on day 5 reached $98.74 \%$. In spite of its high removal efficiency, this system is provably ineffective in the batik industrial wastewater treatment. It is because the treated effluents do not meet the standard quality for the textile wastewater and water quality classifications (class I, II, III, and IV). Both COD and FOG levels are far from the predetermined standards.

\section{REFERENCES}

1. Abdou E.Z., Elgawad A.I. 2016. Constructed wetland as a sustainable wastewater treatment method in communities. Procedia Environmental Sciences, 34, 605-617.

2. Ajayi A.A., Peter-Albert C.F., Ajojesu T.P., Bishop S.A., Olasehinde G.I, Siyanbola T.O. 2016. Biochemical Oxygen Demand and carbonaceous

Table 4. The comparison between effluents generated from hybrid CWs and water classification standards

\begin{tabular}{|c|c|c|c|c|c|}
\hline \multirow{2}{*}{ Parameter } & \multirow{2}{*}{$\begin{array}{c}\text { Treated effluent of hybrid } \\
\text { CWs (mg/L) }\end{array}$} & I & II & III & IV \\
\cline { 3 - 6 } & 1,247 & 10 & 25 & 50 & 100 \\
\hline COD & 48 & 1,000 & 1,000 & 1,000 & 2,000 \\
\hline TSS & 1,020 & 1,000 & 1,000 & 1,000 & $(-)$ \\
\hline Fat, oil \& grease & & & &
\end{tabular}


Oxigen Demand of the Covenant University Sewage Oxidation Pond. Covenant Journal of Physical and Life Science, 4(1), 11-19.

3. Arifan F., Nugraheni F.S., Devara H.R., Lianandya N.E. 2018. Wastewater treatment from batik industries Using TiO2 nanoparticles. IOP Cons. Series: Earth and Environmental Science, 116, 1-6.

4. Birgani P.M., Ranjbar N., Abdullah R.C., Wong K.T., Lee G., Ibrahim S., Park C., Yoon Y., Jang M. 2016. An efficient and economical treatment of batik textile wastewater containing high levels of silicate and organic pollutants using a sequential process of acidification, magnesium oxide and palm shell-based active carbon application. Journal of Environmental Management, 1-11.

5. Cui L., Ouyang Y., Lou Q., Yang F., Chen Y., Zhu W., Luo S. 2010. Removal of nutrients from wastewater with Canna indica L. under different verticalflow constructed wetland conditions. Ecological Engineering, 36, 1083-1088.

6. Cule N., Vilotic D., Nesic M., Veselinovic M., Drazic D., Mitovic S. 2016. Phytoremediation potential of Canna indica L. in water contaminated with lead. Fresenesius Environmental Bulletin, 25(11), 3728-3733.

7. Darsini I.P., Shamsad S., Paul M.J. 2015. Canna indica (L.): A plant with potential healing powers: A review. International Journal of Pharma and Bio Science, 6(2), 1-8.

8. Dehghani M., Sadatjo H., Maleknia H., Shamsedini N. 2014. A survey the efficient removal of fat, oil, and grease in Shiraz municipal wastewater treatment plant. Jentashapir Journal of Health Research, $5(6), 1-4$.

9. Halverson N.V. 2004. Review of constructed subsurface flow vs surface flow wetlands. Westinghouse Savvanah River Company.

10. Gunawan I., Oktiawan W., Hadiwidodo M. 2013. Study capabilities vertical subsurface flow constructed wetlands in cull COD, nitrite and nitrate in leachate water. Journal of Environmental Engineering of Diponegoro University.

11. Indrayani L. 2018. Pengolahan limbah cair industri batik sebagai salah satu percontohan IPAL batik di Yogyakarta. Ecothropic, 12(2), 173-184.

12. ITRC. 2003. Technical and regulatory guidance document for constructed treatment wetland, Interstate Technology Regulatory Council.

13. Jayaweera, M.W., Kasturiarachchi J.C, Kularatne R.K.A., Wijeyekoon S.L.J. 2008. Contribution of water hyacinth (Eichhornia crassipes (Mart.) Solms) grown under Different nutrient conditions to Fe-removal mechanisms in ocnstructed wetlands. Journal of Environmental Management, 87, 450-460.

14. Kamarudzaman A.N., Aziz R.A., Jalil M.F.A. 2011. Removal of Heavy metals from landfill leachate using horizontal and vertical subsurface flow constructed wetland planted with Limnocharis flava. International Journal of Civil and Environmental Engineer, 11(5), 73-77.

15. Meng P., Pei H., Hu W., Shao Y., Li Z. 2014. How to increase microbial degradation in constructed wetlands: Influencing factors and improvement measures. Bioresource Technology, 157, 316-326.

16. Melian J.A.H., Rodriguez A.J.M., Arana J., Diaz O.G., Henriquez J.J.G. 2010. Hybrid constructed wetlands for wastewater treatment and reuse in the Canary Islands. Ecological Engineering, 36, 891-899.

17. Mthembu M.S., Odinga C.A., Swalaha F.M., Bux F. 2013. Constructed wetlands: A future alternative wastewater treatment technology. African Journal of Biotechnology, 12(29), 4542-4553.

18. Mukimin A., Vistanty H., Zen N., Purwanto A., Wicaksono K.A. 2018. Bioequalization-electrocatalytic performance of integrated method for removal of pollutants hand-drawn batik wastewater. Journal of Water Process Engineering, 21, 77-83.

19. Otieno A.O., Karuku G.N., Raude J.M., Koech O. 2017. Affectiveness of the horizontal, vertical and hybrid subsurface flow constructed wetland systems in polishing municipal wastewater. Environmental Management and Sustainable Development, 6(2), 158-173.

20. Panrare A., Sohsalam P., Tondee T. 2015. Constructed wetland for sewage treatment and thermal transfer reduction. Energy Procedia, 79, 567-575.

21. Parvati E., Purwanto A.D. 2017. Time series analysis of total suspended solid (TSS) using landsat data in coastal area berau, Indonesia. LAPAN, 61-70.

22. Perdana M.C., Sutatnto H.B., Prihatmo G. 2018. Vertical subsurface flow (VSSF) constructed wetland for domestic wastewater treatment. IOP Conf. Series: Earth and Environmental Science, 148, 1-9.

23. Peraturan Menteri Lingkungan Hidup Republik Indonesia. 2014. Wastewater Quality Standard. Permen LH RI, "No. 5- Baku Mutu Air Limbah,” 2014.

24. Peraturan Pemerintah Republik Indonesia. 2001. Water Quality Management and Water Pollution Control. PP RI, "No. 82- Pengelolaan kualitas air dan pengendalian pencemaran air," 2001.

25. Rashidi H.A., Sulaiman N.M., Hashim NA., Hassan C.R.C. 2013. Synthetic batik wastewater pretreatment progress by using physical treatment. Advanced Materials Research, 627, 394-398.

26. Sasmaz A., Obek E., Hasar H. 2008. The accumulation of heavy metals in Typha latifolia L. grown in a stream carrying secondary effluent. Ecological Engineering, 33, 278-284.

27. Sembiring E.T.J., Muntalif B.S. 2013. Optimization of leachate treatment efficiency by using constructed wetland. Journal of Environmental Engineering, 17(2), 1-10. 
28. Sharma H.B., Sinha P.R. 2016. Performance analysis of vertical flow constructed wetland to treat domestic wastewater using two different filter media and canna as a plant. Indian Journal of Science and Technology, 9(44), 1-7.

29. Shelef O., Gross A., Rachmilevitch S. 2013. Role of plants in a constructed wetland: Current and new perspectives. Water, 5, 405-419.

30. Sindilariu P.D., Brinker A., Reiter R. 2009. Factors influencing the efficiency of constructed wetlands used for the treatment of intensive trout farm effluent. Ecological Engineering, 35, 711-722.

31. Steelyana E. 2012. Batik : A beautiful culture preserve cultural heritage that ecomonic development and support in indonesia. Inktomi Business Review, 116-130.

32. Sutrisno., Wulandari D. 2018. Multivariate analysis of variance (MANOVA) for enriching educational research results. AKSIOMA, 9(1), 37-53.

33. Stein O.R., Hook P.B. 2005. Temperature, plants, and oxygen: How does season affect performance of constructed wetland?. Journal of Environmental Science and Health, 40, 1331-1342.

34. Tangahu B.V., Ningsih D.A., Kurniawan S.B., Imron M.F. 2019. Study of BOD and COD in batik wastewater using Scipus grossus and Iris pseudacorus with intermitten exposure system. Journal of Ecological Engineering, 20(5), 130-134.

35. UN-Habitat. 2008. Constructed wetland manual. Kathmandu: UN-Habitat Water for Asian Cities Program.

36. Wu H., Zhang J., Ngo H.H., Guo w., Hu Z., Liang S., Fan J., Liu H. 2015. A review on the sustainability of constructed wetlands for wastewater treatment: Design and operation. Bioresource Technology, 1-8.

37. Yadav A.K., Dash P., Mohanty A., Abbassi R., Mishra B.K. 2012. Performance assement of innovative constructed wetland-microbial fuel cell for electricity production and dye removal. Ecological Engineering,47, 126-131. 